\title{
Thermal comfort and settlements quality for eco-settlement based management in Yogyakarta
}

\author{
Djaka Marwasta ${ }^{1, *}$, and Muhamad Nurhidayat $^{1}$ \\ ${ }^{1}$ Department of Environmental Geography, Faculty of Geografi, Universitas Gadjah Mada, Indonesia
}

\begin{abstract}
The aims of this research are to know the settlement quality and thermal comfort and to study the prospect of eco-settlement based settlement planning and management in Yogyakarta City. The research method is quantitative method by combines structured interview, field survey, and secondary data analysis. The settlement quality was obtained through satellite imagery processing and structured interview with purposive sampling technique. The thermal comfort of the settlement was obtained through temperature humidity index (THI) analysis, where the data was taken at the temperature and relative humidity on systematic random sampling (grid). Data analysis was done descriptively by looking at spatial aspect. The results of this research showed that the distribution pattern of settlement quality is spreading. The result of thermal comfort analysis showed that THI value was 27 to 29 . It also showed that the whole area was included in the uncomfortable category. The direction of settlement arrangement based on eco-settlement in the study area was divided into ecological, socio-economic, and institutional aspects. The ecological aspect emphasis on the direction of green open space planning, environmental sanitation management, and waste management. The settlement arrangement of eco-settlement concept should be supported by a compatible institutional system and program.
\end{abstract}

\section{Introduction}

High population growth cannot be separated from the rapid growth of developed urban areas. The population increase is indeed not followed by the extension of urban land use. These problems are generally characterized by an increase in traffic density, high building density, population pressure on land, reduced green open spaces, increased environmental pollution, degradation of land resources and so forth.

The continuous growth of the urban population will encourage the addition of urban facilities and infrastructure. The development of urban areas is indicated by the development of transportation networks, drainage, office buildings, settlements, parks and others. As the urban area is constant, while the need for land for various designations is continuously increasing, this will result in decreasing of urban environmental quality. The decrease in urban environmental quality is indicated by the increased level of air, water and soil pollution, etc. [1].

Increasing land demand in Yogyakarta City caused the higher pressure on land and land-use conversion, especially the conversion into new settlements area. The higher land price and narrowing urban open space caused the increasing or building density, development of slums and squatter settlement as well. The addition of uncontrolled new settlements can lead to the decreasing of settlements quality and the increase of the thermal condition.
This research covered the measurement of settlement quality and thermal comfort of the settlement, which then followed by the consideration of eco-settlement based for settlement planning and management. In detail, the main objectives of this research were: 1) to asses the quality of the settlement environment in the research area. 2) to evaluate the thermal comfort of the settlements in the research area, and 3) Assessing ecosettlements appropriate settlement-based ecosystem settlements in the residential area in Yogyakarta Urban area due to improving the quality settlements and thermal comfort.

\section{Methods}

The research method used was a quantitative method with data collection through a structured interview, field survey and secondary data analysis. The quality of settlement environment was obtained through remote sensing image processing and a structured interview with a purposive sampling technique. The parameters used to analyze the quality of settlement environment were economic characteristics, accessibility, and house building characteristics, environmental sanitation, residential environment characteristics and institutional aspects obtained through structured interviews. While the density of settlements and vegetation coverage obtained through the processing of remote sensing images using ArcGis software.

Thermal comfort of the settlement was obtained through the analysis of temperature humidity index

\footnotetext{
* Corresponding author: jakamar@ugm.ac.id
} 
(THI) with the taking of temperature and relative humidity data by systematic random sampling (grid). Eco-settlement based management was divided into three aspects: ecological, socio-economic and institutional/ institutional. Ecological aspect on ecosettlement based management consist of arrangement of green open space, settlement waste management and environmental sanitation management. Data analysis technique is done descriptively by looking at the spatial aspect.

\subsection{Settlement quality data processing}

The data analysis of the settlement quality was measured through the scoring system obtained by the attenuation and weighting of each variable. The density of the settlements was analyzed at each administrative boundary. The density of the settlements acquired through ArcGIS software processing was obtained through the equation:

$$
\text { Housing Density }=\frac{\text { Roof Coverage }}{\text { Administrative Area }}
$$

Classification:

Density $<40 \%$, good category (score $=3$ )

Density $40 \%-60 \%$, medium category (score $=2$ )

Density $>60 \%$, bad category $($ score $=1)$

(Source: Ditjen Cipta Karya, Ministry of Public Works)

Vegetation coverage or tree protection was analyzed at each administration boundaries that follows the boundary of the stud area in Pandeyan Urban Village. Vegetation coverage or a protective tree obtained through ArcGIS software processing is calculated using the equation:

$$
\text { Vegetation Density }=\frac{\text { Vegetation Coverage }}{\text { Administrative Area }}
$$

\section{Classification:}

Tree coverage $>50 \%$, good category (score $=3$ )

Tree coverage $25 \%-50 \%$, medium category $($ score $=2$ )

Tree coverage $<25 \%$, bad category (

(Source: Ditjen Cipta Karya, Ministry of Public Works)

The quality of the settlement environment was then obtained through the calculation of the environmental quality index of settlements through the following equation:

Settlement Quality $=(\mathrm{A} \times 2)+(\mathrm{B} \times 2)+(\mathrm{C} \times 3)+(\mathrm{D} \times 3)+(\mathrm{Ex} 3)+(\mathrm{F} \times 2)+(\mathrm{G} \times 5)+(\mathrm{H} \times 5)$

\section{Description:}

A: Economic characteristics

B: Accessibility

C: Physical characteristics of house building

D: Environmental sanitation

E: Environmental characteristics of the dwelling

F: Social and institutional aspects

G: Settlement density

$\mathrm{H}$ : Vegetation coverage or tree protection
The result of the calculation of the environmental quality index of settlement is then clustered to get the qualification of settlement environment, through the following equation:

Class Interval $=\frac{\text { Highest Score }- \text { Lowest Score }}{\text { Number of Class }}$

Description:

Class number consists of five grade classes that are very good, good, medium, low, and very low

\subsection{Thermal comfort data processing}

Thermal comfort of the settlement was obtained through measurement of air temperature and relative humidity. Based on data measurement of air temperature and relative humidity, thermal comfort index of settlement is measured using two equations. The equation was an index of inconvenience and a comfort level index based on THI. The equation for calculating the Giles discomfort index modified by [2] as follows:

$$
\mathrm{DI}=\mathrm{Ta}-0.55(1-0.01 \mathrm{RH})(\mathrm{Ta}-14.5)
$$

Description:

DI: Discomfort index

Ta: Dry ball temperature (Celsius)

RH: Relative humidity (\%)

The equation to calculate the comfort level was:

$$
\mathrm{THI}=\frac{0.8 \mathrm{~T}+(\mathrm{RH} \times \mathrm{T}) 500}{500}
$$

Description:

THI: Temperature humidity index (indices of uncomfort)

$\mathrm{T}$ : Temperature $\left({ }^{\circ} \mathrm{C}\right)$

RH: Relative Humidity (\%)

THI value was then classified comfort level through the following table:

Table 1. THI value classification

\begin{tabular}{|l|c|}
\hline Comfort Level & THI \\
\hline Comfort & $<27$ \\
\hline Uncomfort & $27<\mathrm{THI}<28$ \\
\hline Very uncomfort & $>28$ \\
\hline
\end{tabular}




\section{Results and discussions}

\subsection{The quality of settlement environment}

The population in Yogyakarta urban will continue to grow simultaneously with the rapid growth of the region. The number of residents also continues to increase while the land area is always constant. Limited are of urban land will make agriculture land converted into built-up land so that if it continues to occur, it will cause a deterioration of settlement environment quality.

The settlement environment quality in the research area is closely related to the quality of the environment in providing added value for the welfare of its population. It relates to the physical, social and economic components of the population. The quality of the settlement environment is also closely related to the distribution of the population in a region, accessibility and supporting facilities in the settlement environment. Analysis of environmental quality of settlements in the research area is done through several variables. Data collection is done through image processing of Worldview and data collection directly in the field through a structured interview. A review of the quality of the settlement environment is carried out by reviewing each neighborhood.

Overall, the research area has a diverse level of environmental quality of settlements and varies in each neighborhood. Distribution pattern is also spread and do not dominant in one location. Slums are generally associated with the river banks. The better settlement condition on the physical and social aspect, as well as governance aspect, will be followed by the better of quality of settlements. The level of environmental settlement quality is divided into five classes that is ranging from very good, good, medium, bad to very bad. These parameters are obtained through clustering by looking at the lowest and highest scores in the environmental quality index of the settlement.

The result of analysis and classification of settlement environment quality in research area showed that dominantly by the medium quality of settlement,

\subsection{Thermal comfort perception}

Thermal comfort is one aspect of settlement comfort. Thermal comfort is obtained through the measurement of air temperature and relative humidity. The thermal comfort of a settlement can be assessed through THI or Temperature-Humidity Index. From THI method can be produced an index to determine the effect of heat conditions on human comfort that combines air temperature and humidity [3].

The average value of THI in the area was 29.02 with a minimum value of 27.93 and a maximum THI of 29.47. The minimum THI value was observed in the western region while the maximum THI value was in the southern region. The high value of THI is caused by the physical condition of the environment. The research area located in the center of the city makes its territory continues to grow by educational activities, services and trade. These developments lead to a decreasing area of green open space as it impacted by the establishment of various buildings to support the development of the city.

Research area which is traversed by the main road and major roads to the surrounding area caused traffic densely. At some points, especially in the main intersection are often encountered congestion. The density of traffic causes increased air pollution due to emissions or vehicle exhaust. It is also affecting the microclimate conditions in area which resulted in rising air temperatures.

The high temperature that causes high THI value can be reduced by applying good settlement governance. Good governance can be achieved through the arrangement and addition of green open spaces. The addition of green open space proved to reduce air temperature and reduce the THI value. According to Ministerial Regulation no. 72007 on the Setup of Green Open Space Settlement Area, green open space benefits for improving the microclimate of a region [4]. Thermal comfort and calculation results in research area are presented in the following table:

Table 2. Thermal comfort distribution

\begin{tabular}{|c|c|c|c|c|}
\hline \multirow{2}{*}{$\begin{array}{c}\text { Point } \\
\text { Sampling }\end{array}$} & \multicolumn{2}{|c|}{ Coordinate } & \multirow{2}{*}{ THI* } & \multirow{2}{*}{ Classification } \\
\cline { 2 - 3 } & $\mathbf{X}$ & $\mathbf{Y}$ & & \\
\hline 1 & 431459 & 9135986 & 27.93 & Not comfortable \\
\hline 2 & 431657 & 9135857 & 28.46 & Very uncomfortable \\
\hline 3 & 431716 & 9135505 & 28.40 & Very uncomfortable \\
\hline 4 & 431558 & 9136184 & 28.29 & Very uncomfortable \\
\hline 5 & 431645 & 9136658 & 28.90 & Very uncomfortable \\
\hline 6 & 432075 & 9136627 & 28.79 & Very uncomfortable \\
\hline 7 & 431979 & 9136285 & 28.79 & Very uncomfortable \\
\hline 8 & 432077 & 9135904 & 28.80 & Very uncomfortable \\
\hline 9 & 432066 & 9135491 & 28.82 & Very uncomfortable \\
\hline 10 & 432252 & 9135199 & 29.04 & Very uncomfortable \\
\hline 11 & 432379 & 9135563 & 29.29 & Very uncomfortable \\
\hline 12 & 432360 & 9136003 & 29.09 & Very uncomfortable \\
\hline 13 & 432353 & 9136254 & 28.94 & Very uncomfortable \\
\hline 14 & 432446 & 9136679 & 28.96 & Very uncomfortable \\
\hline 15 & 432718 & 9136578 & 29.39 & Very uncomfortable \\
\hline 16 & 433038 & 9136469 & 29.22 & Very uncomfortable \\
\hline 17 & 433029 & 9136200 & 29.05 & Very uncomfortable \\
\hline 18 & 432686 & 9136258 & 29.09 & Very uncomfortable \\
\hline 19 & 432727 & 9135805 & 29.10 & Very uncomfortable \\
\hline 20 & 432983 & 9135897 & 29.08 & Very uncomfortable \\
\hline 21 & 433057 & 9135451 & 29.21 & Very uncomfortable \\
\hline 22 & 432809 & 9135499 & 29.33 & Very uncomfortable \\
\hline 23 & 432777 & 9135158 & 29.47 & Very uncomfortable \\
\hline 24 & 433080 & 9135163 & 29.39 & Very uncomfortable \\
\hline 25 & 432755 & 9134919 & 29.34 & Very uncomfortable \\
\hline 26 & 443080 & 9134804 & 29.37 & Very uncomfortable \\
\hline 27 & 433441 & 9135268 & 29.26 & Very uncomfortable \\
\hline 28 & 433449 & 9135613 & 29.31 & Very uncomfortable \\
\hline 29 & 433401 & 9135873 & 29.34 & Very uncomfortable \\
\hline 30 & 433423 & 9136303 & 29.30 & Very uncomfortable \\
\hline & & & & \\
\hline
\end{tabular}

*THI: Temperature Humidity Index 


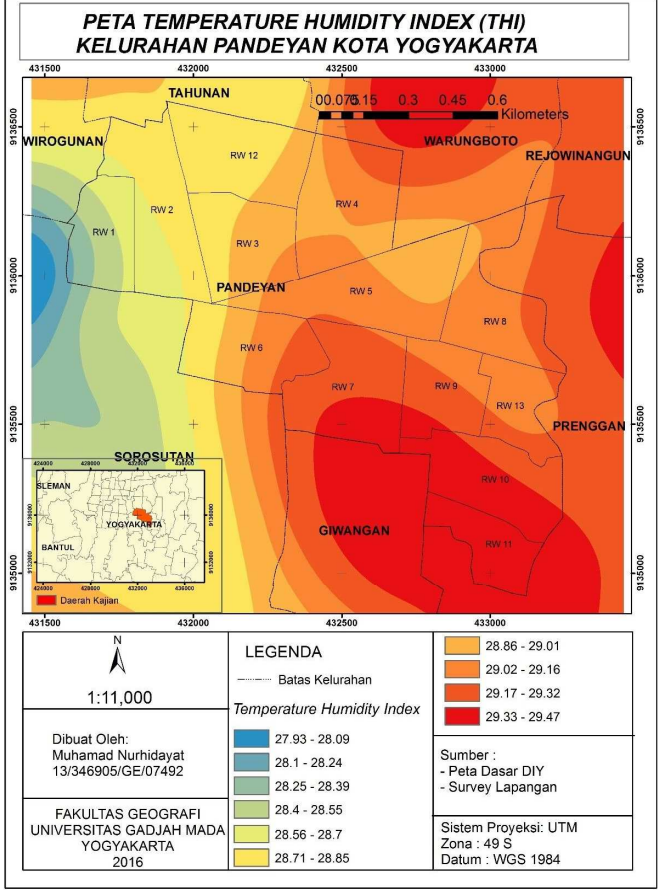

Fig 1. THI Map.

\subsection{Eco-settlements}

Eco-settlement is a residential area as an ecological residence. The concept of eco-settlement can be said to be the development of the concept of sustainable development because it harmonizes the physical and social aspects. According to Suryani [5], Eco-settlements is a concept of settlement arrangement that harmonizes social, economic and ecological aspects towards the sustainability of ecosystems supported by a capable institutional system.

\subsection{Ecological aspects of settlement arrangement}

Eco-settlement concept is closely related to the direction of the physical condition of the settlement environment. The ecological aspects are intended to improve the quality and comfort of settlements for supporting environmentally sound city development. Ecological based on settlement aspects can be realized through the arrangement of green open spaces, the management of sanitation settlements and waste management settlements.

The result of green open space priority study in research area shows 2 priority of green space that is priority 1 and priority 2. Characteristic of a bad settlement environment causing some areas to be prioritized for green open space development. Priority 1 green open space is located in the Southern part. Priority 2 of green open space is in the western area.

Priority 1 of open green space or highly prioritized has poor to very bad quality environmental characteristics, high-density settlements, low vegetation coverage, and uncomfortable settlement comfort levels. Priority 2 of open green space has high-density settlement characteristics, low vegetation coverage, uncomfortable settlement comfort level but good quality of settlement up to very good. Areas with Priority 1 are expected in the future to add green open spaces built and managed by governments and communities together.

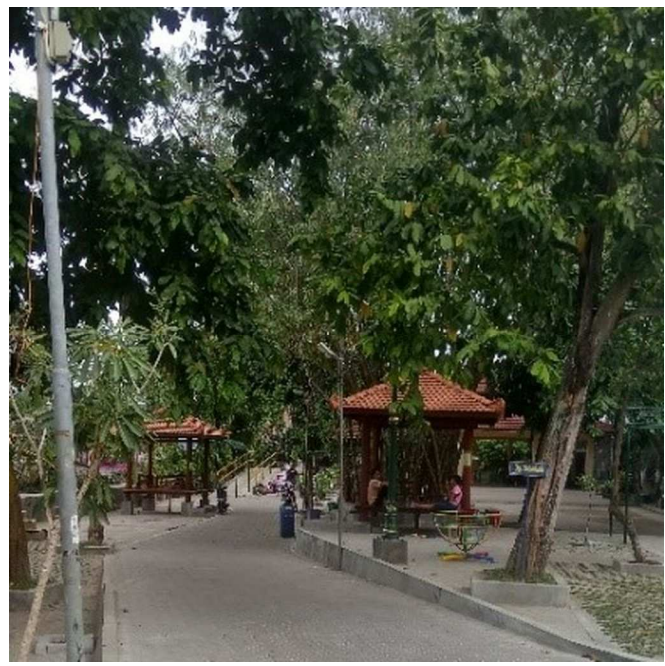

Fig. 2. Green Open Space [6].

Green open space is always synonymous with ample space and planted with various vegetation or trees arranged in such a way. Whereas green open space is not always fixed on large land. If glued to a large area of land, a narrow land in urban areas makes the green open space, of course, challenging to develop and difficult to establish. The green open space in the settlement area is divided into green open spaces of point, line or line and area. Green open space in the form of lines and dots do not need land that is so vast that it is suitable to be applied in a big boxota that is solid enough.

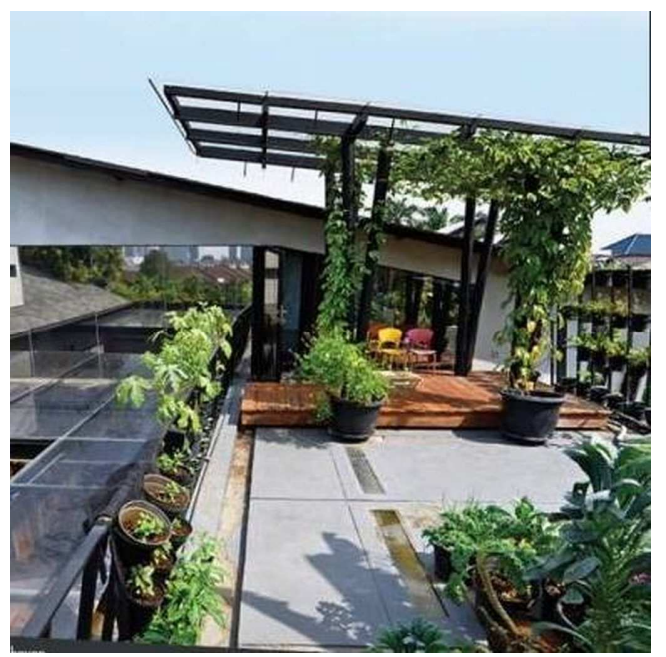

Fig. 3. Green Open Space Concept (Kusumawijaya, 2017).

Eco-settlements based can also be realized through good sanitation and waste management to create a clean and healthy environment. A clean settlement environment is everyone's dream. A clean environment can create the healthiest environment furthest from various seeds of disease so as to create a beautiful and 
comfortable environment. A clean and healthy environment can be realized through good environmental sanitation management. Environmental sanitation by Notoadmojo [7] is an environmental health status that includes housing, sewerage, water supply etc.

Sanitation of a reasonable settlement environment needs to pay attention to several aspects such as clean water conditions, drainage and non-flooded drains, clean toilets, integrated household waste disposal systems, waste management settlements that apply the $3 \mathrm{R}$ concept (reduce, reuse, recycle) and so forth.

\section{Conclusion}

The quality of the settlement environment in the research area is calculated through the scoring method by considering the physical, social and economic aspects. There are five parameters of settlement quality ranging from very good, good, medium, bad and very bad. The distribution pattern of quality of settlement tends to spread and not dominant in one location. The average slum settlement is associated on the river banks. The better the settlement area in terms of physical, social and governance of settlements, the better the quality of the settlements.

Thermal comfort of settlements in research area obtained through THI by measuring the temperature and relative humidity. The analysis of THI value in is estimated to be 27 to 29 . It shows that all of its territories is included in the uncomfortable category. The high temperature that causes high THI value can be reduced by applying good settlement management one of them through arrangement and addition of green open space.

The direction of settlement arrangement of the ecosettlements concept is divided into ecological, socioeconomic and institutional aspects. The ecological aspect emphasizes the direction of green open space arrangement, environmental sanitation management and waste management applying the concept of $3 \mathrm{R}$ or reuse, reduce and recycle. The settlement arrangement of the eco-settlement concept must harmonize the physical, social and economic aspect supported by the kinibel institutional system.

\section{References}

1. Priyana Y. Tata Ruang Dan Pengembangan Wilayah Kabupaten Dati II Boyolali. Jurnal Forum Geografi 23/XII/Desember 1998 ISSN 0852-2682 (1998)

2. Widyastuti, Anita, Penggunaan Foto Udara dan Sistem Informasi Geografis Kerapatan Tutupan Vegetasi di Kota Yogyakrta. Skripsi. Fakultas Geografi UGM (2002)

3. Ahmad, R. and Hidayat, M, Tingkat Kenyamanan Termal Bagi Pengguna Taman di Jakarta. Jakarta: Universitas Mercu Buana (2014)

4. Peraturan Menteri Dalam Negeri No. 7 Tahun 2007 tentang Penataan Ruang Terbuka Hijau Kawasan Permukiman. Jakarta: Kementrian Dalam Negeri
5. Suryani, A, Tantangan Implementasi Konsep EcoSettlement dalam Undang-Undang No. 1 Tahun 2011 Tentang Perumahan Dan Kawasan Permukiman. Pusat Pengkajian, Pengolahan data dan informasi sekretariat jendral DPR RI, Aspirasi Volume 2/ No.1, Juni (2011)

6. Fandeli, C. Kaharuddin dan Muklison, Perhutanan Kota. Yogyakarta: Fakultas Kehutanan UGM (2005).

7. Notoadmojo, Soekidjo, Ilmu Kesehatan Masyarakat "prinsip-prinsip dasar". Jakarta: Rineka Cipta (2003) 